\title{
The Role of Pekanbaru Food and Drug Administration Centre in the Circulation of Snacks for School Children Containing Harmful Substances in Pekanbaru
}

\author{
Ahmad Fuadi ${ }^{*}$, Rosyidi Hamzah ${ }^{2 *}$, Admiral $^{3}$, Fadhel Arjuna Adinda ${ }^{4}$ \\ ${ }^{I}$ Postgraduate Department of Law Science, Universitas Islam Riau, Indonesia \\ ${ }^{2 *}$ Postgraduate Department of Law Science, Universitas Islam Riau, Indonesia \\ ${ }^{3}$ Postgraduate Department of Law Science, Universitas Islam Riau, Indonesia \\ ${ }^{4}$ Postgraduate Department of Law Science, Universitas Islam Riau, Indonesia \\ *rosyidihamzah@law.uir.ac.id
}

\begin{abstract}
Advances in technology and science have changed the way food and drug are produced. The circulation of Snacks for School Children (PJAS) that contained harmful substances in Pekanbaru City calls for serious attention. In buying snacks at school, children tend to only see the external appearance of the food without knowing whether or not there are harmful substances in the food. This is caused by the lack of knowledge regarding possible harmful substances that may be contained in the food. Factors causing snack makers to use Harmful Food Additives (BTP) include ignorance factor, deliberate factor and public purchasing power factor. The role of Pekanbaru Food and Drug Administration Centre (BBPOM) in the circulation of Harmful Snacks for School Children is insignificant due to limited authority in taking action against business actors who violate the law. Therefore, a fundamental change is needed to the laws and regulations governing the authority of FDA to take action against perpetrators of violations of the circulation of food and drugs, both criminal, administrative and civil.
\end{abstract}

Keywords: Pekanbaru Food, Drug Administration Centre, School Children

\section{INTRODUCTION}

Advances in technology and science have changed the way food and drug are produced. These days, the mass production of food has utilized the combination of machine and human power and added new substances to enhance the appearance and the taste of the food. Competition among food makers is getting fiercer, compelling them innovate in terms of shapes, flavors and price. The incessant advertising for food products also has an effect on increasing public consumption. However, on the other hand, public knowledge and compliance with harmful substances contained in food is still very low.

For this reason, the state must act to protect the public from the circulation of harmful substances contained in food. The role of the government in this matter is reflected by the establishment of the Food and Drug Administration (FDA). FDA is a nonministerial government agency that exacts governmental authority in the field of food and drug control [1]. In addition, the government should stipulate a set of regulations regarding food and drug that aims to protect the interests of the general public which include the interests of legal protection for security, order, welfare and health[2]. The development of society and law continues to keep pace with the times. Although there are times when the law still has struggled to keep up with it.

The role of the FDA is to supervise the circulation of food and drugs in the market and provide guidance to business actors. The supervision carried out by FDA on food products directly plays a role in protecting consumers from food products that are not suiTABLE forconsumption. Supervision of food products means that FDA is actively involved in safeguarding consumer rights, namely maintaining consumer safety and security, (article 4 letter a of Law Number 8 of 1999 on Consumer Protection)..

Even with the presence of consumer protection and food product control authority, act of fraudulence still occurs among business actors. They commit fraud by manipulating products they are selling. These manipulative actions include selling products past their expiry date, selling products using prohibited food additives, selling recycled products unsuiTABLE for consumption, and selling products that do not meet the health standards set by the government. Food is an energy source for humans. When food is mixed with harmful substances it can damage organs and health. The prevalent finding of harmful substances in food sold 
to school children must receive serious attention from the government and other relevant parties. Children are the asset of the nation who will continue the undertaking and leadership. Therefore, children must be protected since the early age from the exposure of elements that can impair their development, one of which is food that contains harmful substances.

The circulation of Snacks for School Children that contain harmful substances in Pekanbaru City calls for serious attention. Children tend to only see the external appearance of the food without knowing whether or not there are harmful substances in the food. This is caused by the lack of knowledge regarding possible harmful substances that may be contained in the food.

The discovery of toxic ingredients in food suggests that the supervision exercised on processed food vendors is still weak, even though legal sanctions against food and beverage sellers who do not comply with the standards required by Law Number 8 of 1999 concerning Consumer Protection are quite severe, namely 5 years in prison and a fine of $\mathrm{Rp} 2,000,000,000$ (two billion rupiah). In fact, vendors still have enough audacity to sell food and drinks that contain hazardous substances to consumers. On the other hand, the FDA commands very limited authority to take action against perpetrators who sell snacks or food containing dangerous food additives. Based on the discovery of Riau Province FDA regarding snacks containing additives, it is suggested that the enforcement of the consumer protection law, health law, food law and child protection law is still poor, even though food and beverages that are deliberately mixed with harmful substances are detrimental to health and may even cause death [2].

Based on the background presented above, the author was intrigued to examine it deeper due to the known effects of harmful additives to children and consumers in general. Health is the most important thing for everyone and intake of harmful substances to the body will have negative impact and may even cause death. Therefore, the author embarked on a research titled "The Role of Pekanbaru Food and Drug Administration Centre in the Circulation of Snacks for School Children Containing Harmful Substances in Pekanbaru City".

\section{RESEARCH METHOD}

By the type, it was an observation research conducted by the means of a survey, which was direct research to the research location using data collection tools in the form of interviews and questionnaires. By the design, it was a descriptive analytic study, which was a research intended to provide a detailed, clear and systematic description of the main research problems. The object of this research was Consumer Protection for elementary school students against ready-to-eat food that was consumed in the form of snacks containing additives/dangerous substances that were sold without much control in schools.

As suggested by the title of the study, this study was conducted at the FDA of Riau Province and elementary schools. These locations were preferred because the author was able to obtain necessary and relevant data do the study. The population and respondents were snack vendors in the vicinity of elementary schools in Pekanbaru City and the Head of Pekanbaru FDA. The data collection tools were interviews and questionnaire.

\section{RESULT AND DISCUSSION}

Continuous progress in the fields of technology, economy and politics demands the strengthening of the role of the state in all aspects of people's lives. The presence of this state is to provide protection for the interests of the general public and to participate in realizing the greatest possible justice and prosperity[3].

If consumers feel harmed by business actors related to the goods they consume, then the business actor must be responsible in accordance with Article 19 of Law No. 8 of 1999 concerning Consumer Protection, in which the business actor is obliged to provide compensation for damage, contamination and/or consumer losses due to consuming goods and/or services produced or traded. However, in reality, consumers admit that they are confused about where to fight for their rights if something harmful happens to them. Ultimately, they chose to remain silent and overcome these losses at their own expense without asking for compensation from the business actor concerned. The questionnaire distributed by the author to the respondents contained this question: Are you aware of the quality of food and beverages (snacks) that are suiTABLE for consumption by your children? The responses were presented below: 
TABLE 1. Responses on the quality of food and beverages (snacks) that are suiTABLE for consumption by young children

\begin{tabular}{|c|l|c|c|}
\hline No. & Respondents' Answers & Quantity & Percentage (\%) \\
\hline \multirow{2}{*}{} & Aware & 12 & $100 \%$ \\
& Unaware & - & $\%$ \\
\hline \multicolumn{2}{|c|}{ Total } & 12 & $100 \%$ \\
\hline
\end{tabular}

Source: Processed Data in the Field in 2019

From the TABLE above, it could be seen that overall, 12 respondents/ten people $(100 \%)$ reported that they are aware of the quality of food or drinks (snacks) that were suiTABLE for consumption by school children.As elaborated in the background that food products were relied on by consumers as a source of daily protein. However, consumers were not aware that these food products contained additives or hazardous substances. The food products in question were widely found in school snacks, market snacks, catering food, even in supermarkets which are a form of modern markets.Food is a basic human need that is needed at anytime and anywhere and requires good and correct processing in order to benefit the body. The four main functions of food for human life are to:

- Maintain body in the process of growth/development and replace damaged body tissue.

- Obtain energy for daily activities.

- Regulate metabolism and balance of water, minerals and other body fluids.

- Regulate body's defense mechanisms against various diseases.

Determination of food quality in general is highly dependent on several factors, such as taste, texture, nutritional value, and also microbiological characteristics. However, before other factors are taken into account, visually the color factor comes first and is often very decisive. Apart from being a determining factor for quality, color can also be used as an indicator of freshness or ripeness. The proper mixing method or processing method can be indicated by the presence of a uniform and even color[4].

In Article 1 point 5 of the Regulation of the Head of the Food and Drug Administration No. 37 of 2013 concerning the Maximum Limit for Use of Color Additives, it is explained that natural food coloring are dyes made through the process of extraction, isolation, or derivatization (partial synthesis) of plants, animals, minerals, or other natural sources, including naturally identical dyes.

The results showed that most of the food producers had poor knowledge regarding Food Additives that were prohibited from being used. Apart from that, the factor of economic interest is also one of the reasons for business actors to use dangerous additives in their products. This was conveyed by the Head of the Food and Drug Inspection Section in the author's interview.

The questionnaire distributed by the author to the respondents contained this question: Has your child ever consumed snacks that were not suiTABLE for consumption? The responses were presented below:

TABLE 2. Responses on the knowledge of fraudulent business actors who deliberately mix their products with hazardous materials that are not suiTABLE for consumption

\begin{tabular}{|l|l|l|l|}
\hline No. & Respondents' Answers & Quantity & Percentage $(\%$ \\
\hline $\begin{array}{l}1 . \\
2 .\end{array}$ & Yes & 12 & $\begin{array}{l}100 \% \\
-\%\end{array}$ \\
\hline \multicolumn{2}{|l}{ Total } & - & $100 \%$ \\
\hline
\end{tabular}

Source: Field Processed Data for 2019

From the TABLE above, it could be seen that all 12 respondents $(100 \%)$ stated that they never consumed snacks unfit for consumption. The reason parents said that their children have never consumed snacks was because this was not known by the parents of students, because it was their children who bought the snacks and not them.

The deliberate factor included economic interest in which business actors wanted to gain maximum profit and they did not want to lose/spend high production cost; business actors were ignorant of the prevailing laws and regulations and they did not think about the consequences or dangers of their products. The purchasing power factor of society includes the consumer factor itself, where the community or consumers wanted a cheap product regardless of its quality. They do not care whether the food they ate contained dangerous food additives 
or not. According to the author's opinion, elementary school students cannot distinguish which snacks contained and did not contain dangerous additives, because these school children did not know at all about the existence of substances used by fraudulent business actors to sell to school children and the school did not inform about the Food Additives which was dangerous or prohibited from being used.The questionnaire distributed by the author to the respondents contained this question: Have you ever heard of fraudulent business actors who deliberately mix their products with hazardous materials that are not suiTABLE for consumption? The responses were presented below:

TABLE 3. Responses on the knowledge of fraudulent business actors who deliberately mix their products with hazardous materials that are not suiTABLE for consumption

\begin{tabular}{|l|l|l|l|}
\hline No. & Respondents' Answers & Quantity & Percentage $(\%$ \\
\hline 1. & Yes & 12 & $\begin{array}{l}100 \% \\
-\%\end{array}$ \\
2. & No & - & $100 \%$ \\
\hline \multicolumn{2}{|l|}{ Total } & 12 & $12 \%$ \\
\hline
\end{tabular}

Source: Field Processed Data for 2019

From the TABLE above, it could be seen that all 12 respondents $(100 \%)$ stated that they were aware of the existence of fraudulent business actors who deliberately mix their products with hazardous materials that are not suiTABLE for consumption. Based on the author's field survey, many schoolchildren snacked on food or drink containing bright colored hazardous food additives that were unknown to elementary school children. Meanwhile, the vendors who were interviewed by the author knew the details of hazardous Food Additives, but only one kind and only heard it from television. Sarpi admitted that he did not know what kinds of food additives were dangerous. He only knew formaldehyde, because he often heard it on television. He also did not know that the food he was selling was mixed with any ingredients, because he did not make it himself but bought it from Pasar Bawah in Pekanbaru City[5].

\section{CONCLUSION}

The role of Pekanbaru Food and Drug Administration Centre (BBPOM) in the circulation of Harmful Snacks for School Children is insignificant due to limited authority in taking action against business actors who violate the law. It is limited because in practice, they have to coordinate with other relevant law enforcement entities. Several laws and regulations explicitly state the prohibitions and sanctions on food production. For this reason, a fundamental change is needed to the laws and regulations governing the authority of the FDA to take action against perpetrators of violations and against the distribution of food and drugs both criminal, administrative and civil.

\section{ACKNOWLEDGMENTS}

This study is Research Grants by The Ministry of Research and Technology/the National Agency for Research and Innovation of the Republic of Indonesia year 2020 and LPPM Universitas Islam Riau to support this research.

\section{REFERENCES}

[1] Donald Albert Rumokoy and Frans Maramis, PengantarIlmu Hukum. Jakarta: Rajawali Press, 2016.

[2] Kaelan, Negara Kebangsaan Pancasila. Yogyakarta: Paradigma, 2013.

[3] Ismi Marya, "Peran Penyidik Balai Besar Pengawas Obat Dan Makanan Dalam Penegakan Hukum PidanaTerhadap Pelaku Penjual Obat Keras Tanpa Kewenangan," J. Poenali, vol. 2, no. 4, 2014.

[4] Soerdjono Soekanto \& Budi Sulistyowati, Sosiologi Suatu Pengantar. Jakarta: Rajawali Press, 2014.

[5] Elli Ruslina, Dasar Pemikiran Indonesia DalamPenyimpangan Mandat Konstitusi UUD Negara Tahun 1945. Jakarta: Total Media, 2013. 